\title{
A Sketch of a System of Theory and Practice
}

\author{
James Alexander
}

Bilkent University

Most political theorists are committed to one particular view about the relation between theory and practice. It is argued in this article that there are in fact four possible ways of relating theory and practice, which are distinguished in terms of the answers that are given to two distinct questions. Derived from this is the suggestion that all political theorists can be classified according to whether they are sanguine, phlegmatic, melancholic or choleric. The purpose of this sketch of a system is to indicate the questionable nature of much of what passes for modern political theory - especially that of the now dominant sanguine tradition, which has for several decades especially concerned itself with the 'impact' theory can have on practice.

Keywords: theory; practice; impact; humours

If we believe the foreshortened history offered by Habermas in Theory and Practice, then the problem of the relation between theory and practice arose when the Aristotelian assumption that politics was concerned with the good life was replaced by the Hobbesian assumption that politics was concerned only with life as such - its preservation and propagation (Habermas, 2007 [1971], pp. 41-2.) This, of course, is far too simple since everyone knows that the history of politics can hardly be read from the pages of books like the Politics or Leviathan. But it does indicate something about the problem of theory and practice: their reconciliation appears to be the hope (or condition) of one tradition of political philosophy and their separation appears to be the hope (or condition) of another. There are different names for these traditions. I will go on in this article to call them, not without warrant, but certainly without much originality, 'radical' and 'liberal'. It should be said that Habermas's own attempt to solve the problem with an obscure recession into Kant, Hegel and Marx is hardly to be outdone for deliberate obfuscation. Here I do not suppose that the problem of theory and practice can be solved, but I do think that it is possible to say something clear about it.

Most modern-day political philosophers are less troubled about the problem than Habermas was in 1971. Ever since the Rawlsian moment in the history of political philosophy - incidentally, also in 1971 - there has been a convenient division of labour by which the 'political theorists' have declared themselves to be the experts on the ought of politics, thereby establishing themselves alongside the 'political scientists' who had declared themselves for several decades to be the experts on the is of politics. After half a century of anxiety, political philosophy was justified. Empirical on the one side, normative on the other; 'scientists' and 'theorists' could regard each other with tolerance.

Something like this division of labour appears to be behind the argument Thom Brooks put forward in May 2013 in Political Studies Review when he said that theorists ought to welcome the requirement that their 'research' should have 'impact'. Everyone, I think, knows what 'impact' means: influence, somehow, on the world as measured by 
various governmental and professional agencies, and, more grandly and without inverted commas, any sort of influence that political philosophers have had in the world. Brooks' argument was in the form of Benjamin Franklin's argument, mocked so well by D. H.

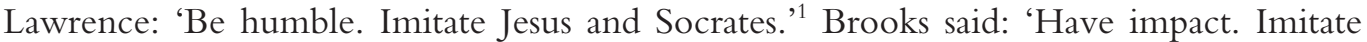
Aristotle, Locke and Kant.' What he meant in practice, as he also said, is 'Imitate Rawls'. And 'Imitate Parekh, Plant and O'Neill'. And 'Imitate Nussbaum, Miller and Mendus'. And perhaps even, we are meant to suppose, 'Imitate Brooks' (Brooks, 2013). The problem is that Brooks' argument, if taken seriously, would, I think, lead to the death of political theory in all but one possible sense. In this short article, instead of arguing against Brooks point by point - which would be to take what is a disputable and even disreputable argument too seriously - I shall sketch a theory that will put his model of political theory into its proper place.

The view that a political theory ought to have an 'impact' certainly depends on a particular view of the relation between theory and practice. This view is that theory is something carried out antecedently on its own terms to establish standards, principles or norms, which are then consequently imposed on practice. 'Political philosophy', Philip Pettit (2014, p. 190) has recently declared, is 'a guide to what we can do in politics'. It offers us an end, an aim, a structure, a procedure, a compass, a blueprint, a road map. One can see why a political theorist who believes this is likely to be persuaded that 'impact' is a meaningful metaphor. The theorist throws a theory into the world of practice where it has an impact. ${ }^{2}$ Now, this is not an entirely preposterous idea (even if we think that it is preposterous to think we could measure the 'impact' that theory could have on practice, or that an academic could have on society), though I myself think it flawed. It is clearly an influential idea among political philosophers. It is held by many of them: consciously by some, unconsciously by more. In an interesting volume of interviews entitled Political Questions (Ebbe and Nielsen, 2006) around twenty political theorists were asked about the relation between theory and practice. Most of them declared that theory and practice should have some sort of relation. A few admitted to doubts. But all except one took for granted what I will later call a 'sanguine' conception of the relation between the two. ${ }^{3}$ This indicates something of the difficulty. Very few theorists acknowledge, or perhaps even know, that there are different ways of conceptualising the relation between theory and practice, and that perhaps we ought to begin by considering the differences between them. This is where I shall begin.

What follows is an original theory of how theory relates to practice. ${ }^{4}$ The argument is that theory and practice can be related in four ways. The fourfold argument is not an arbitrary one, but rather is generated by imposing two distinctions on an otherwise rather intractable subject matter. The first distinction is between seeing theory and practice as separate worlds and seeing them as different elements of one world. It may be that theory and practice are wholly separate, so that when we engage in theory we occupy a world untainted by practice; or it may that they are wholly intertwined, so there is no such thing as a theory untainted by practice or practice untainted by theory. The former view would commit us to something like a Platonic position, in which theoria is a contemplative activity enabling us to rise above our local conditions and, indeed, our doxa, so that we might understand theory as something properly philosophical, an activity which 
takes us somehow out of this earth. The latter view would involve a rejection of such a traditional and hierarchical way of seeing philosophy. Instead of seeing the philosopher or theorist as someone 'not of this earth', straining to reach the ideal, the truth or the divine, we would declare that all theories are human-all-too-human and very much of this earth, of this world. I think that ever since Plato this issue has been disputed. We could perhaps arrange Aristotle, Augustine, Aquinas, Descartes, Kant on one side, and Protagoras, Machiavelli, Montaigne, Hobbes, Bentham and Nietzsche on the other. I don't insist on these lists of authorities: it is enough to say that the dispute was there when Protagoras and Socrates argued, and it is with us still.

Let us state the antinomy so it is clear:

Theory and practice are two worlds, or

Theory and practice are parts of one world.

If the former, then there is such a thing as a separable 'theory', untainted by practice. A philosopher, then, is someone who seeks such theories, has some insight into the beyond or the invariant. If the latter, then there is no such thing as a separable theory. And then the philosopher is something else, perhaps not a philosopher at all. And all 'theories' would then be conditioned by, and perhaps even constituted by, practical concerns. Both of these are eminently thinkable.

I think the rather vexed question of the difference, if there is one, between political philosophy and political theory originates here. It could be, of course, that the difference between political philosophers and political theorists is that theorists read newspapers, while philosophers do not. But there is good reason to think that the distinction between them could only really matter to someone who believed that 'philosopher' should only be used of someone who believes that 'theory and practice are two worlds' and that 'theorist' should only be used of someone who believes that 'theory and practice are parts of one world'. This seems to be how Michael Oakeshott meant it when, in 1961, on reviewing Peter Laslett's edition of Locke's Two Treatises, he said that Locke's work was

not a work of political philosophy, like Leviathan, but a work of 'political theory' - the questionable enterprise of recommending a political position in the idiom of general ideas. ... Locke, like many other writers, recognises no firm distinction between explanation and prescription; he moves, often inadvertently, between these two disparate worlds of discourse, giving a specious air of principle to his recommendations and a false suggestion of practical applicability to his explanations (Oakeshott, 2008, p. 163).

In a similar manner Hannah Arendt thought that philosophers (she, of course, had the great example of Heidegger) tended to misunderstand politics. So in 1964 when someone called her a philosopher, she replied: 'I'm afraid I have to protest. I do not belong to the circle of philosophers. My profession, if one can speak of it at all, is political theory' (Lilla, 2001, p. 40). If the terms are not to be used interchangeably, then this would be one way of distinguishing them. The problem is that there are some like Pettit who call themselves political philosophers even though Oakeshott would call them political theorists, and there are also some like Alain Badiou (2010, p. 38) who claim that political philosophers are 'nothing more than erudite servant[s] of capitalo-parliamentarianism': that is, in Oakeshott's sense, political theorists. The point, for the moment, is that the 
important thing to establish is not the name, but the structure of the assumptions any particular 'theorist' or 'philosopher' makes about the relation between theory and practice. This is why I shall use 'philosophy' and 'theory' interchangeably in the rest of this article.

The second distinction is more subjective. It has to be distinguished from the objective one about whether theory and practice should be thought of as forming two worlds or parts of one world. It is, no matter what we think about the first question, whether we think that theory and practice can meaningfully be related to each other by us in our understanding of what we are doing. This may not seem very clear, so let me say more about it. I have already quoted Oakeshott making a distinction between explanation and prescription; between saying how things are, really are and saying how things should be, whether or not we think that the way things are is how they really are or how they appear to be. The point about explanation is that it attempts to be objective, a view from nowhere, whereas prescription is a view from somewhere, and therefore subjective. As Martin Buber, Martin Heidegger and others in various ways suggested a century ago, there is a great difference between saying 'It is' and ' $I$ am', or between speaking of the relation 'I-It' and the relation 'I-Thou'. To say 'Politics is $\mathrm{x}$ ' is to say something radically different from saying 'Politically, I am x' or, even better, 'I do x'. Or to put it in terms of explanation and prescription, we can of course appeal to detached explanatory assumptions about the status of theory and practice and what we suppose their fundamental, or formal, relation to be, but then we can explore the assumptions that lie behind what we suppose ourselves to be doing when we engage in theory and practice: and derive from them prescriptions for others and justifications for the self. So there are two questions, one in terms of 'It is' and one in terms of 'I am':

1. What is the formal relation between theory and practice?

2. What is your actual sense of how your theory and practice are related - or how other people's theory and practice are related?

We could say that the first is a more theoretical question, and the second a more practical one. But it should be noted that although both questions can only be asked by someone interested in political philosophy, in the first question we can bracket out any particular political philosopher or politikos (statesman) or polites (citizen), while, in the second we cannot.

The responses to these two questions can be simplified if we rewrite them so that the answer to either can only be 'Yes' or 'No'.

1. Are theory and practice formally separate? That is, do you think it is possible to come up with a theory which is untainted by the world and uncorrupted by practice?

2. Are theory and practice, for you, in your practice, related? That is, whatever you think about the first question, do you think that the way you theorise something can be related to practice in some definite way? Is there something that can be done?

To these two questions, there are two answers - 'Yes' and 'No' - and so four possible positions, depending on whether a particular political philosopher answers 'Yes, Yes', 'Yes, No', 'No, No' or 'No, Yes'. Each position is an ideal, of course, since it is very 
unlikely that many actual political philosophers have given coherent or consistent answers to these questions (most would probably say 'Well-'), and it is of course very likely that even those who have given coherent answers will then go on to contradict themselves in their own theory and practice. To make the answers clear, I shall summarise each position in ordinary language. The first is the standard position of political philosophers and theorists today (including, I think, Brooks):

A. Can I come up with a theory untainted by practice? Yes. Do I think that I can make something out of such a theory in the world of practice? Yes. I think that theory and practice are separate. I can come up with theories in my ivory tower and conceptualise the good without corruption: this is obviously a good thing, theoretically. But there is no reason for you to accuse me of being out of touch for I then try to implement my ideal in practice, or at least suggest that it should be implemented, before handing it over to lawyers, political scientists, politicians so they can do so.

B. Can I come up with a theory untainted by practice? Yes. Do I think that I can make something out of such a theory in the world of practice? No. I think that theory and practice are formally separate. To explain something academically is not to propose that it should be defended or changed. It follows, for me, that whatever I come up with theoretically, in effect, is not meant for outside the ivory tower. It is meant to help us understand the world, not change it. Supposing that philosophy or theory can change anything in politics is not only vulgar; it is ignorant.

C. Can I come up with a theory untainted by practice? No. Do I think that I can make something out of such a theory in the world of practice? No. I think that theory and practice are inextricably related, and that any serious view of politics depends on our seeing that this is so. We are formed by our historical circumstances and often hold our views for entirely contingent reasons. So I think we cannot remain in the ivory tower. Yet I don't think that there is any clear causal relation between theory and practice that would enable us to establish simply, if at all, an exact way for theory to benefit practice. Instead, we must remain vigilant about the continual interrelation of the two. In short, one cannot separate oneself from politics, but it is very hard, if not impossible, to say what should be done.

D. Can I come up with a theory untainted by practice? No. Do I think that I can make something out of such a theory in the world of practice? Yes. I think that theory and practice cannot formally be distinguished since they both exist within an ideological framework in an identifiable historical situation. It follows that to theorise is to engage in practice, to engage in practice is to enact a theory and, indeed, that to recognise consciously the interrelation between the two is to commit oneself to certain radical or critical practices that are the appropriate correlates at any one time of an appropriate theory. In other words, one can engage in politics and one, in a sense, always knows what should be done.

They are ideals, and extreme ones, but they are not ideals which are so extreme that they have not received fairly close approximation in the writings of some more or less coherent and consistent political philosophers. Of course, in many actual cases 'No' will mean 'Not really' and require further elaboration (and that is assuming the answer is not merely 'Well-'). In addition, 'something' could vary from 'something a bit better than nothing' to 'something which will change the world irrevocably'. And so on.

(C) 2015 The Author. Political Studies Review (C) 2015 Political Studies Association

Political Studies Review: 2015, 13(4) 
But, even with that said, and with all qualifications made, it should be obvious to everyone that $\mathrm{A}$ is the pure ideal of Rawls, say, or Pettit or, indeed, most political philosophers and theorists in the American and English world and now increasingly elsewhere. D is the ideal of Marx and all Marxists, many para-Marxists and even, complicatedly, some post-Marxists (although the complications sometimes involve paradoxical refractions of the other answers). These two positions, $\mathrm{A}$ and $\mathrm{D}$, are famous because they are positive in the most straightforward political sense: they both say 'Yes' to the second question. They are in that sense optimistic, and can be contrasted with the other two, pessimistic positions. These positions have been stated in English very clearly by writers associated, oddly enough, with Cambridge: B by Michael Oakeshott (1933) and Maurice Cowling (1963), and C by John Dunn (2001) and Raymond Geuss (2008).

Broadly speaking, the first two answers, $\mathrm{A}$ and $\mathrm{B}$, are liberal; the second two, $\mathrm{C}$ and $\mathrm{D}$, are radical. To say this may even help us make sense of the difference between liberals and radicals. A radical is someone for whom theory and practice cannot be separated from each other, so that one always goes in theory to the root of practice, and in practice to the root of theory. 'Root' is of course radix, hence radical: an eater of roots. A liberal is someone for whom theory and practice can be bracketed off from each other, so that theory is theory and practice is practice, and they can be dealt with within their own categories quite apart from the vexed matter of relating them to each other. If a radical is an eater of roots, a liberal is an eater of leaves. And everyone is liberal or radical, or some confused blend of the two: even reactionaries, the religious and anarchists. Some of us are liberal in one context and radical in another. We could be, for instance, liberal about secular politics but radical about theological politics. Or vice versa.

At various times I have come up with different names for the four positions, which I will mention here, since it seems worth trying to capture the meanings of these differences in a memorable way. We could call them, following what I have just said: A. liberal optimist, B. liberal pessimist, C. radical pessimist, D. radical optimist. However, for a time I thought that the best way to distinguish the four positions would be to call those who think theory and practice are separate worlds 'externalists' and those who think they are not 'internalists'; and to call those who think that theory and practice can have a relation 'credulous' and those who do not (or doubt that they can) 'sceptical'. This would give us: A. credulous externalist, B. sceptical externalist, C. sceptical internalist, D. credulous internalist. However, since these terms are a bit arcane, I am tempted instead to use terms from classical Greek medicine. Just as Hippocrates and Galen distinguished four elements air, water, earth and fire in terms of four characteristics (cold and hot, dry and wet) and associated a humour with each element - sanguine with air, phlegmatic with water, melancholic with earth and choleric with fire - so the names of these humours can be used as a mnemonic for the four ways of relating theory and practice.

A Sanguine: Theory and practice are formally separate, but can be related.

B Phlegmatic: Theory and practice are formally separate, and cannot be related.

C Melancholic: Theory and practice are formally interrelated, but the relation is intractable.

D Choleric: Theory and practice are formally interrelated, and the relation is tractable. 
These form a fourfold as symmetrical as that of the original four humours. And what is useful about these names is that they do capture something in the nature of each view about theory and practice. A political philosopher who is sanguine supposes that theories can be framed like policies for implementation. He or she is hopeful, like most of the theorists of Political Questions and, I assume, like Brooks. One who is phlegmatic lets the world go to the dogs with equanimity and simply writes philosophy where he or she can. One who is melancholic thinks that although things can be done, and are being done, the relation between these things and what is thought about them is intractable even if undeniable. And one who is choleric thinks something can be done, should be done and is being done whether we admit it or not. Of course no metaphor should be taken too far. These names are proposed here as a mere convenience. If they capture the imagination of the reader, then good; if not, then they may be forgotten. It is the distinction between the positions, and not their names, that is the important matter.

I have to say that in politics I am closest to the phlegmatic position. The melancholic has some appeal, especially when expressing criticism of other positions, but seems to involve utter defeat (unless it has an obscure religious commitment), whereas the phlegmatic position is defiant as well as being sceptical. Yet even the credulous or optimistic positions of the sanguine liberal and the choleric radical have some interest in attempting to defend what I - it should be obvious that I am sceptical rather than credulous - suppose are wholly untenable positions about normativity, on the one hand, and praxis or rupture, on the other. Yet it is strictly irrelevant to say what my own humour is. The point is that all political philosophers, all political theorists and all students of both or either should recognise the existence of all four humours, traditions or paradigms - call them what you will. The problem with so many modern academics in politics is that they only recognise one, or at most two: and usually the two which are, to my mind, flawed.

It is not original to say that we should recognise the significance in what others are saying, and recognise the significance of the fact that some of these others can say things which contradict what others of those others are saying. Half a century ago Maurice Cowling (1964) wrote:

At the risk of seeming uncouth, or a danger to the profession of political philosophy, one must repeat that political philosophy should be thought to begin, not by clarifying a tradition of moral or political practice, but by pursuing the implications of the fact that different traditions of practice are everywhere in conflict. ... The 'truth' that should be written on ... the hearts of all political philosophers is not that the good should be willed or justice done - for we are all in favour of justice - but that conceptions of good are many.

Hardly anyone has fully incorporated this suggestion into their understanding of the problems of political philosophy. Cowling wrote nothing substantial after The Nature and Limits of Political Science (Cowling, 1963) and so left it at that. Since then there has been Alasdair MacIntyre (1985), who has emphasised the existence of 'rival traditions' in ethics. There has been John Dunn, whose essays are in essence a prolonged meditation on our inability to say anything decisive in a situation in which there are rival traditions (e.g. Dunn, 1979). And there has been Andrew Vincent (2004), who has written the best 
book about the rival traditions evident in contemporary political theory. Otherwise, political philosophers have remained in their various liberal and radical dead ends.

Political philosophy should begin, then, not by clarifying any one tradition emerging out of its history, but by recognising the fact that different traditions are now everywhere in conflict. It is not clear what the impact of this sort of thought is likely to be. My own view is that politics is likely to benefit most from thought that is both historical and philosophical; or to put it another way, which attends to both authorities and arguments, both contingencies and necessities, while seeing the necessity in contingency and the contingency in necessity - and the contradictions in evidence throughout. For instance, I would go so far as to say that a fundamental principle of modern political philosophy should be:

There is now no way to demonstrate that philosophy trumps politics or that politics trumps philosophy: it is not even that they are the ends of a scale, running grey from white to black. There is no continuity here: on the contrary, there is discontinuity, since any philosophical position is open to the simple rupturing argument that all philosophical positions are political before they are philosophical, and any political position is open to the simple rupturing argument that all political positions can be subjected to philosophical interrogation. There is, therefore, no way that any political philosopher can ever claim priority for politics over philosophy or for philosophy over politics without making a mistake even if this is what they have to do in order to come up with a coherent theory of politics.

Our duty is to recognise that the possibility of adopting a political or a philosophical ground is always open, and that the two possibilities form an antinomy that can never be resolved. I think my sketch of a system of theory and practice does recognise this. Talk of 'impact', alas, does not. It commits us in advance to one, possibly flawed, position, and prevents us from putting this position to question. It is for this reason that I think that the rhetoric of 'impact' will only further divide labour and diminish returns. It will commit us to further creative accounting in relation to our own 'impact', and to further minuscule theorising in ideologically, academically and politically correct manner. Above all, it will encourage only one form of literature, namely, the autistic literature of the sanguine political theorists.

(Accepted: 31 January 2015)

\section{Notes}

1 'The amusing part is the sort of humility it displays. "Imitate Jesus and Socrates" and mind you don't outshine either of those two' (Lawrence, 1971 [1923], p. 18).

2 This is before we get to the ambitious subaltern academic subculture that is concerned with 'non-ideal theories' which are supposed to ensure that 'ideal theories' have impact. I don't see how mentioning Rawls in one breath and Realism in another is going to rescue normative theory for practice.

3 The exception was Chandran Kukathas (Ebbe and Nielson, 2006 pp. 68-9), who said: 'Oakeshott was right. I think John Rawls was seriously mistaken in thinking that political philosophy is public discussion taken to a higher level of abstraction.'

4 An original theory is necessary since, as far as I know, none exists. For anyone wanting to think about these matters, I would recommend, as good preliminaries: Oakeshott (1962, 2004), Heller (1984, pp. 146-51), Rawls (2001, pp. 1-5), Badiou (2005, p. 10), Geuss (2008, p. 55) and even Rancière (2010). Habermas (2007 [1971]) should be read with caution (insofar as it is not read with exasperation). Floyd and Stears (2011), to take one recent contribution, is, despite appearances, an attempt to make fundamental difficulties seem trivial ones. Its cumulative effect is to do nothing other than sanction current practices. 


\section{References}

Badiou, A. (2005) Metapolitics. Trans. J. Barker. London: Verso.

Badiou, A. (2010) The Communist Hypothesis. Trans. D. Macey and S. Corcoran. London: Verso.

Brooks, T. (2013) 'In Defence of Political Theory: Impacts and Opportunities', Political Studies Review, 11 (2), $209-15$.

Cowling, M. (1963) The Nature and Limits of Political Science. Cambridge: Cambridge University Press.

Cowling, M. (1964) 'Problems of Orthodoxy', Spectator, 25 September.

Dunn, J. (1979) Western Political Theory in the Face of the Future. Cambridge: Cambridge University Press.

Dunn, J. (2001) The Cunning of Unreason: Making Sense of Politics. New York: HarperCollins.

Ebbe, M. and Nielsen, J. (eds) (2006) Political Questions: Five Questions on Political Philosophy. Copenhagen: Automatic Press.

Floyd, J. and Stears, M. (eds) (2011) Political Philosophy versus History? Contextualism and Real Politics in Contemporary Political Thought. Cambridge: Cambridge University Press.

Geuss, R. (2008) Philosophy and Real Politics. Princeton, NJ: Princeton University Press.

Habermas, J. (2007 [1971]) Theory and Practice. Cambridge: Polity Press.

Heller, A. (1984) Radical Philosophy. Trans. J. Wickham. Oxford: Basil Blackwell.

Lawrence, D. H. (1971 [1923]) Studies in Classical American Literature. Harmondsworth: Penguin.

Lilla, M. (2001) The Reckless Mind: Intellectuals in Politics. New York: New York Review Books.

MacIntyre, A. (1985) Three Rival Versions of Moral Enquiry: Encyclopaedia, Genealogy, Tradition. London: Duckworth.

Oakeshott, M. (1933) Experience and Its Modes. Cambridge: Cambridge University Press.

Oakeshott, M. (1962) 'The Study of Politics in a University', in M. Oakeshott (ed.), Rationalism in Politics and Other Essays. London: Methuen, pp. 318-33.

Oakeshott, M. (2004) 'What is Political Theory?', (c. 1970) in M. Oakeshott (ed.), What is History? and Other Essays. Exeter: Imprint Academic, pp. 391-401.

Oakeshott, M. (2008) The Vocabulary of a Modern European State. Exeter: Imprint Academic.

Pettit, P. (2014) Just Freedom. New York: W.W. Norton.

Rancière, J. (2010) 'Ten Theses on Politics', in J. Rancière (ed.), Dissensus: On Politics and Aesthetics. Trans. S. Corcoran. New York: Continuum, pp. 27-44.

Rawls, J. (2001) Justice as Fairness: A Restatement. Cambridge, MA: Belknap Press.

Vincent, A. (2004) The Nature of Political Theory. Oxford: Oxford University Press.

\section{About the Author}

James Alexander teaches in the Department of Political Science at Bilkent University in Ankara, Turkey. He is the author of 'The Four Points of the Compass' (Philosophy, 2012), 'The Contradictions of Conservatism' (Government and Opposition, 2013), 'Notes towards a Definition of Politics' (Philosophy, 2014), 'The History of Political Philosophy' in The Bloomsbury Companion to Political Philosophy (Bloomsbury, 2015) and 'The Three Major Ideologies of Liberalism, Socialism and Conservatism' (Political Studies, 2015). James Alexander, Department of Political Science, Bilkent University, 06800 Ankara, Turkey; email: jalexand@bilkent.edu.tr 